\title{
TYPES OF DOCUMENTS ON THE HISTORY OF THE TURKESTAN CENTURY KEPT IN THE NATIONAL ARCHIVES OF UZBEKISTAN
}

\section{L.I. Salomova}

Lecturer National University Of Uzbekistan Tashkent, Uzbekistan

\section{ABSTRACT}

This article provides a brief overview of the diversity, quantity, purpose and requirements for documentation of documents on the history of the Turkestan Autonomous Soviet Socialist Republic, stored in the National Archives of Uzbekistan. The role of the electronic document, registered in electronic form, confirmed by the electronic digital signature, the external analysis of the source of paper documents, the order of the documents, the order documents, organizational documents, information documents, service correspondence were studied from the source.

KEYWORDS: - National Archive of Uzbekistan, Turkestan ASSR Documents, fund, list, collection, history.

\section{INTRODUCTION}

Among the documents stored in the National Archives of Uzbekistan, we can get information about the history of the Turkestan ASSR from $\mathrm{R}$ funds. These funds are a database formed and preserved in the processes related to the field of office work of state institutions of the Turkestan ASSR.

Documents are also diverse and quantitative The purpose, direction, size, shape, and a number of other qualities of many documents also vary. Therefore, in addition to the general requirements for the language of documents, there are many requirements for the work of compiling each category of documents.

A particular type of document is, of course, defined by its specific linguistic features and qualities. It is impossible to create a perfect documentary without a comprehensive, in-depth consideration of these features and qualities. Therefore, the issue of document classification is of particular importance here.

In documentation, documents are classified according to several aspects. Although there is no exact grouping in the classification, it is still possible to group them in a somewhat unified manner.

\section{THE MAIN FINDINGS AND RESULTS}

According to this tradition in the field of documentation, documents in the office are classified, first of all, according to the place of structure. In this respect, internal and external documents differ. Internal documents are documents created in the same institution and used within the same institution, and those that 
CURRENT RESEARCH JOURNAL OF HISTORY 2(11): 73-77, November

2021

DOI: https://doi.org/10.37547/history-crjh-02-11-15

ISSN 2767-472X

(C2021 Master Journals

\section{Crossref doi) 80 Google}

Accepted 25 $5^{\text {th }}$ November, 2021 \& Published 30 ${ }^{\text {th }}$ November, 2021

come to a particular institution from another organization or individual are external documents.

Documents are mainly used as a source to shed light on history. However, few of the documents accepted for storage in the archives are accepted for permanent storage. Not all of the adopted documents can be presented as a historical source. They are a historical source only if they are introduced into scientific consumption by society. After a certain stage in the activity of archival work, the process of source studies is transferred. At this point, the notion of the value of a document emerges, and this notion reveals the source significance of the document. In distinguishing between an archival document and a historical source, taking into account the authenticity, historicality and many other important aspects of the document, today the terms archival document and historical source are closely related. In an era of modern technology, the types of documents are also increasing.

An electronic document is an information recorded in electronic form, certified by an electronic digital signature and having other details of the electronic document that allow it to be identified. When the documents in the funds belonging to the history of the Turkestan ASSR, stored in the National Archives of Uzbekistan, are classified from the point of view of historical sources, they are divided into forms: paper and microfilm. Work is underway to create electronic copies. According to the report of the Department of Electrification of Archival Documents of the National Academy of Sciences of Uzbekistan in 2020, to date, 77 collections of the R-25 fund on the history of the Turkestan ASSR have been collected. 67 collections of R-17 fund were collected, 3 collections from R-18 fund, 1 collection from R-29 fund, 2 collections from R-20 fund are fully digitized. Digital copies of them in Pdf, TIFF format are available. The main purpose of creating digital copies of archival documents is to provide researchers with a view to time, and these copies are also a digital heritage of documents. At the same time it serves as a means of transmitting documents to the next generation and their insurance copy.

Copies of a number of micro-filmed documents on the history of the Turkestan ASSR are also kept in the National Archives of Uzbekistan. Microfilmed documents are insurance copies of these archival documents, the first microfilming was carried out in 1964 [1].

When paper documents on the history of the Turkestan ASSR kept in the National Archives of Uzbekistan were analyzed from the outside, most of the information was written in Russian. Some documents are written in Russian on one side and in Uzbek on the other in the Arabic alphabet. After the establishment of the Soviet government, all documentation and office work in the country was conducted mainly in Russian. Examples of official documents in Russian on the one hand and in Uzbek on the other in the Arabic alphabet are the Turkestan MIQ orders in the R25 fund. It is about control over the implementation of orders and directives of local executive committees in the water departments of the Turkestan MIQ and HKS, which is indicated in the Russian text as "Circular". On the Uzbek side, the translation of the word is "Open command", in some places "Open letter" [2]. It can be concluded that the Turkestan ASSR can be recognized not only as a source of historical information, but also as a source of information about the rules of procedure, history and linguistics of the organization [3].

It can be said that the main reason why the R215 collection No. 74 of the National Archives of Uzbekistan has been restored as an old document is that its top layer is not covered with 
CURRENT RESEARCH JOURNAL OF HISTORY 2(11): 73-77, November

2021

DOI: https://doi.org/10.37547/history-crjh-02-11-15

ISSN 2767-472X

(C2021 Master Journals

\section{Crossref doi) 80 Google}

Accepted 25 $5^{\text {th }}$ November, 2021 \& Published 30 ${ }^{\text {th }}$ November, 2021

hard cardboard. For this reason, it is necessary to carry out repair work in this document. As for the size of the document, its height is $34 \mathrm{~cm}$. The sheets, $25 \mathrm{~cm}$ wide, were typed on thin paper in Russian on a typewriter and in manuscript. Typewritten notes are corrected on the pen. It is also possible to observe the invisibility of the typewriters by sticking them together on paper, for a total of 146 sheets. Department of Water Resources of the Republic of Turkestan Order №38 26.11.22 Water use program in Turkestan. List of measures of the Department of Water Resources. Explanatory note on the implementation of the water management plan of the Republic of Turkestan ASSR for 1922. Report on the situation in the Republic of Turkestan and its future tasks. This document covers the year 1922. There is also a list listed in the sequence at the beginning of the document.

Documents related to the Turkestan ASSR stored in the National Archives of Uzbekistan can be classified according to the order of their operation as follows. Order documents, organizational documents, information documents, service correspondence [4].

Orders of decrees include decrees, laws, orders, circulations, resolutions, orders, decisions, etc.

As a result of the implementation of laws and decrees, it is important to study the activities of government executive bodies in the Turkestan ASSR. Through the orders, decrees, decisions stored in their archives, it is possible to obtain information about the measures taken in the implementation of the law in the framework of their duties.

Among the types of documents stored in the funds, the decisions of the Council are an important source of information.

For example, the R-29 fund retains the decision of the Land Affairs Council. According to one such document, lands belonging to the royal family, Russian colonialists and local wealthy people, along with agricultural equipment and buildings, were confiscated in all regions of Turkestan. The sr-water committees played a major role in carrying out this work. In the elections to the provincial, county, and volost land and water committees from January 1918, it was explained to the villagers that their main task was to implement the land law. Despite the armed struggle against the Soviet regime, by July 1918, 43 land and water committees were established in Samarkand region" [5].

Report documents found in the funds of the Turkestan ASSR, kept in the National Archives of Uzbekistan, belong to the executive bodies, which provide analytical information and suggestions on the issues raised for discussion. In evaluating them as a historical source, the information provided in them is taken into account. Because the documents provide more general information about the institution's activities, more historians deal with this type of document. An analysis of the reports and reports of the funds of the Turkestan ASSR suggests that the annual reports of the higher and executive bodies for 1918-1919 covered 1-3 years of data. However, as a result of the Soviet government's deteriorating economic situation in Turkestan in 1918-1920, the post-New Economic Policy report of 1921 provided an analytical summary of 5,10 , and even 20 years of data.

Among the funds stored in the archives can be seen a lot of statistics about the Turkestan ASSR. Such data can be found more in the reports of the Central Statistical Office, as well as higher organizations. A lot of historical data can be obtained through statistics. The statistics of the Turkestan ASSR can be seen as a source of information on agriculture, population structure, domestic and foreign trade, culture, finance. 
CURRENT RESEARCH JOURNAL OF HISTORY 2(11): 73-77, November

2021

DOI: https://doi.org/10.37547/history-crjh-02-11-15

ISSN 2767-472X

(C2021 Master Journals

Crossref doi

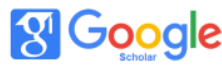

Accepted 25th November, 2021 \& Published 30th November, 2021

According to the importance of providing generalized information to the Turkestan ASSR documents can be divided into several types: Reporting documents, Historical essays, Cartographic, tabular and graphic documents.

Reporting documents are documents that provide information on the completion of work or tasks planned for a certain period of time, the results of practical work, which are prepared annually, semi-annually or before congresses. They are an important historical source that testifies to the work done by the departments during their tenure.

According to page 42 of this fund, after the October 1917 coup, the water system in Turkestan was in dire straits, and the restoration of water facilities required a large workforce. Lack of a single irrigation management system, misuse of water, bureaucracy, and increased bureaucracy were cited as factors contributing to the deteriorating water situation in the country. The volume of irrigated land during the First World War was 2,400,000 desiatinas $(2,619,360$ hectares), but by 1920 it had dropped to $1,400,000$ desiatinas $(1,527,960$ hectares $)$ [6].

A lot of historical data can be identified in the process of conducting research. For example, in the National Archives of Uzbekistan, the R-29 Fund of the Turkestan People's Commissariat of Agriculture, List 3, Collection 2448 contains an important historical essay on the history of irrigation in Turkestan.

When paleographically analyzing the documents of the Turkestan ASSR in the National Archives of Uzbekistan, most of the documents contain text or symbols written in pencil.

In addition, most of the documents in the funds are typed. Typewritten archival documents used dark gray, blue, purple, and black. It should be noted that the purple texts of the archival documents have become very blurred and invisible, while the black texts are well preserved.

Among the documents belonging to the Turkestan ASSR, there are a small number of manuscripts. Manuscripts can often be found in the fund of the Commissariat of Agriculture, in the fund of the Turkestan Water Department, in the fund of the Turkestan Water Department, in the information documents of experts in the study of water problems in Afghanistan and Iran.

Due to the state of preservation of the collections and the fact that the covers are very old, a large number of collections have been replaced by modern covers by the Department of Archival Document Restoration, but not repaired [7].

When the archival collections were analyzed from the outside, some collections were skin thick and well preserved, their thickness being $0.3 \mathrm{~cm}$, height $38 \mathrm{~cm}$, and width $23 \mathrm{~cm}$. While the blue inscriptions on it are blurred, the black inscriptions are clear and well preserved [8].

\section{Conclusion}

In summary, among the funds on the history of the Turkestan ASSR in the National Archives of Uzbekistan can be found more than 40 types of documents, each of which has historical significance.

According to the above data, an analysis of the materials of these documents shows that the historical role of archives in enriching the country's history with new information is incomparable.

It should be noted that documents on the history of the Turkestan Autonomous Soviet Socialist Republic, stored in the National Archives of Uzbekistan, need to be repaired.

REFERENCES 
CURRENT RESEARCH JOURNAL OF HISTORY 2(11): 73-77, November

2021

DOI: https://doi.org/10.37547/history-crjh-02-11-15

ISSN 2767-472X

(C)2021 Master Journals

Crossref dof 81 Google

Accepted 25th November, 2021 \& Published 30 ${ }^{\text {th }}$ November, 2021

1. www.archive.uz/. News of archives of Uzbekistan, 21.10.2010.

2. NAU, R-25 fund, list 1 , collection 1206 , page 25 .

3. Choriev Sh.Sh. Funds of the Central State Archive of the Republic of Uzbekistan - as a source of coverage of economic processes in the Turkestan ASSR. Tashkent: 2018. -p. 30.

4. Aminov M., Madvaliev A. Stationery. Toshkent: 2000. - pp. 11-42.

5. NAU, R-29 fund, list 3, collection 1068, page 67.

6. NAU, R-29-fund, list 3, collection 2448, page 42 .

7. Choriev Sh.Sh. Funds of the Central State Archive of the Republic of Uzbekistan Turkestan as a source of coverage of economic processes in the ASSR., Tashkent: 2018, page 34 .

8. NAU, R-25-fund, list 1, external analysis of the collection 1051.

9. Rakhmankulova, Z., Choriev, S., Yusupova, D., \& Muminov, O. (2020). The Historiography Of The Relations Between Central Asian Khanates And Ottoman Empire In The 19 th And At The Beginning of The 20 th Centuries. International Journal of Scientific and Technology Research, 9(2), 311-318.

10. Choriev, S. S. (2019). The history of Baltic nation diaspora in Uzbekistan. Theoretical \& Applied Science, (2), 19-25.

11. Choriev, S. S. (2017). CLASSIFICATION OF THE TURKESTAN ASSR DOCUMENTATION IN THE CENTRAL STATE ARCHIVE OF THE REPUBLIC OF UZBEKISTAN. ISJ Theoretical \& Applied Science, 12(56), 50-54.
12. Чориев, Ш. Ш. (2016). Из истории формирования фондов государственных органов Туркестанской АССР. Документ. Архив. История. Современность.Екатеринбург, 2016, 209-212. 